\title{
ГРОМАДЯНСЬКА ЛІРИКА ІВАНА ФРАНКА, Iї ХУДОЖНІ ОСОБЛИВОСТІ
}

\begin{abstract}
Стрюк Л. Б., Ткачук К. С. Громадянська лірика Івана Франка, їі художні особливості.

У статті досліджено художні особливості всіх циклів, що входять до збірки І. Франка «3 вершин і низин». Визначено, що провідними художніми засобами для громадянської лірики поета $\epsilon$ зіставлення, паралелізм, інакомовність, персоніфікація, насиченість риторичними конструкціями, антитезами, розгорнутими метафорами, порівняльними зворотами, поетичними звертаннями та ін. Громадянській ліриці поета властива пристрасність, внутрішня енергія поривання до боротьби зі злом, соціальною неволею, горем та упослідженням народу. Ліричне «я» постає борцем за волю і щасливе майбутнє для України і демократичних верств.
\end{abstract}

Ключові слова: інакомовність, персоніфікація, алегорія, метафора, стилістичні фігури, громадянська лірика.

Стрюк Л. Б., Ткачук К. С. Гражданская лирика Ивана Франко, eе художественные особенности.

В статье исследуются художественные особенности всех циклов, входящих в сборник И. Франко «С вершин и низин». Акцентируется внимание на том, что доминирующими художественными средствами для гражданской лирики поэта являются сопоставления, параллелизмы, иносказательность, персонификация, насыщенность риторическими конструкциями, сравнениями, поэтическими обращениями и т.д. Гражданской лирике поэта свойственна эмоциональная насыщенность, страстность, внутренняя энергия стремления к борьбе со злом, социальной неволей, горем и унижением народа. Лирическое «я» - это борец за волю и счастливое будущее для Украины и демократических слоев населения.

(ㄱ Л. Б. Стрюк, К. С. Ткачук, 2018. 
Ключевые слова: иносказательность, персонификация, аллегория, метафора, стилистические фигуры, гражданская лирика.

Stryuk L. B., Tkachuk K. S. The civil lyrics of I. Franko, its artistic features.

The article examines the artistic features of all cycles included in the collection of I. Franko "From the tops and lowlands". It is determined that the dominant artistic means for civic lyrics of the poet are juxtaposition, parallelisms, allegorical meaning, personification, saturation with rhetorical constructions, comparisons, poetic appeals, epithets, hyperboles, repetitions, sound patterns, antonyms, synonyms, folklore elements, key words (struggle, bondage, grief, tears, blood, battle, chains, poverty, torment, crying, hard work, sadness, freedom, truth), and etc. The poet's civic lyrics are characterized by emotional saturation, passion, inner energy of striving to fight evil, social bondage, grief and humiliation of the people. The lyric "I" is a fighter for the liberty and a happy future for Ukraine and the democratic segments of the population. The civil lyrics of the poet present a number of relationships: man and society, man and nature, ideal and reality. The lyric "I" opposes the negative moral and social phenomena of the era, accuses the state system of anti-humanity, anti-nationality. The poet emphasizes on such phenomena of reality as oppression, hopelessness, poverty, grief, hunger, meanness, cynicism, disregard, back-breaking toil, etc. He urges to overcome the dominance of evil, lie, despotism and injustice in society. The bearer of positive is represented by a man of labor against the background of a generous nature in his works. Most of the civil lyrics works are imbued with tragic-dramatic pathos, which is caused by the irreconcilable conflict of the lyrical "I" with anti-human reality. Contrasts of the social life of the lower classes and pictures of humiliation of a person are inseparable from the motives of his greatness and spiritual strength, faith in a better future for the people. I. Franko's civil lyrics are characterized by ideological overtones, the leitmotif of the struggle against despotism of the upper classes, publicistic and romantic rhetoric, and a call for struggle for freedom and independence. The language of works is artistically rich and aphoristic. The poet believed in the power of the artistic word. The dominant images are images of fire, clouds, thunderstorm, rainstorm, wind, sun, stars, which grow into symbolic images in his works. The lyrics of the poet are intellectual in content, differ social optimism, belief in the victory of good over evil, light over darkness. I. Franko skillfully conveys the peculiarities of the author's worldview, and the lyrical "I" via creating associative fields.

Key words: allegorical meaning, personification, allegory, metaphor, stylistic figures, civil lyrics.

Оновлення, яке відбувається в суспільному житті, зумовлює нові підходи в дослідженні художніх творів. На сучасному етапі розвитку науки велику увагу науковці приділяють їх глибокому 
текстуальному вивченню, оскільки «високохудожній твір сповнений глибоких, актуальних сенсів, <..> поетика високохудожнього твору дає змогу по-справжньому відкрити «секрети художності» [5, с. 5]. Упродовж багатьох десятиліть в аналіз художніх творів штучно привносилися такі політичні акценти, які об'єктивно не випливали зі змісту цих творів, не диктувалися життям і творчою діяльністю митця, приглушувався загальнолюдський зміст літератури, іiї художній потенціал. У наш час потребує переосмислення творчість письменників-класиків, зростає увага до художнього тексту, до нової його інтерпретації, звільненої від кон'юнктури. 3 огляду на це важливим $\epsilon$ перепрочитання поетичних творів І. Франка, які відповідають потребам сучасності щодо духовного збагачення молоді, усвідомлення української самоідентифікації «у розумінні етнічної і / або політичної нації», морально підготувати іiі до ситуації екзистенційного вибору [8, с. 2]. Тому дослідження громадянської лірики I. Франка, iї художніх особливостей $\epsilon$ актуальним i своєчасним.

Герой Франкової лірики, як вважав С. Сфремов, виступає на захист активності, екзистенційної боротьби особистості. Однак це не простий бунт проти обставин у дусі соціальної боротьби, це діяльність як філософія буття особистості, як художньофілософський маніфест - філософія активності та неспокою, vitaeactivae, світоглядне кредо, яке С. Єфремов вкладає у тріаду «життя - праця - боротьба» [4, с. 170].

О. Білецький у статті «Поезія Івана Франка», говорячи про вихід збірки «3 вершин і низин», писав: «Це була найвизначніша після «Кобзаря» Шевченка подія в українській поезії XIX ст.» [1, с. 193]. Оскільки в цій збірці, за твердженням М. Дубини, прозвучали «мотиви викриття тогочасного ладу», вона «піднесла українську політичну лірику на новий, вищий щабель» [3, с. 48].

I. Франко, як зазначав М. Ткачук, «прагнув виводити лірику на широку дорогу художнього пізнання сучасної та історичної

(ㄱ Л. Б. Стрюк, К. С. Ткачук, 2018. 
дійсності, а особливо поглиблювати суб'єктну сферу моделювання внутрішнього «Я» як «іншого», «випромінювання-Я» (по-німецьки Ausstrahlungen des Ichs), що створює простір для випромінювання його кількох «Я»> ... Його поезія відбила душевні шукання герояекзистенціала, який болісно, як i автор, переживав «сирітство духовне» [7, с. 35]. Франкова концепція людини, на думку О. Романенка, - діяльна, його ліричний герой здатний бути причиною змін у власному житті та й у житті усього суспільства. Його внутрішній неспокій, його передчуття оновлення трансформуються в перетворення суспільні, природні, психоемоційні [6, с. 100-101].

Т. Гундорова відзначала, що вперше видана 1887 р. і згодом доповнена й перевидана 1893 р. збірка «3 вершин і низин» - свого роду підсумкова на творчому шляху поета. До першого видання включено незначну частину поезій, написаних протягом 18771887 років. Друге, значно розширене видання, організоване за поетичними циклами, жанрово й стилістично багатофункціональне, тематично різнопланове, можна вважати зразковим в українській літературі кінця XIX ст. [2, с. 287]. Поетичні твори цієї збірки, на іiі думку, зорієнтовані на актуальність і дохідливість, пройняті громадянськими асоціаціями, виростають із реального досвіду [2, c. 291].

Більшість дослідників уважає вірш «Гімн» своєрідним прологом до збірки «3 вершин і низин» - першим у світовій літературі гімном революційній та волелюбній ідеї, яка здавна хвилювала людські душі, збуджувала прагнення до кращого життя. Це гімн духу, що «рве за поступ, щастя й волю» [9, с. 43]. Синонімічним повтором, уведеним у риторичну конструкцію поет констатує: «Він не вмер, він ще живе!» [9, с. 43]. Цей дух персоніфікується, він «о власній силі йде», «міuнніє, I cnimuть туди, де дніє: Словом сильним, мов трубою, Міліони зве з собою» [9, с. 43]. Образ світлого майбутнього інакомовно постає у фразі «mуди, де дніє», а порівняльний зворот «мов трубою» передає

-205- Л. Б. Стрюк, К. С. Ткачук, 2018. 
силу закличного голосу, що згуртовує, пробуджує прагнення до кращого майбутнього, «добувати хоч синам, як не собі, Крашу долю в боротьбі» [9, с. 44]. Поет повтором заперечної частки «ні» підкреслює незнищенність волелюбного прагнення в народові: «Hi попівськії тортури, Ні тюремні царські мури, Ані війська муштровані, Ні гармати лаштовані, Ні шпіонське ремесло В гріб його ще не звело» [9, с. 44]. Образ «злої руїни» [9, с. 44] - це символ ворожої народу влади, що породила в країні місця «недолі $\check{u}$ сліз» [9, с. 43]. Образ борців за волю постає в символічному образі нестримної лавини, яку ніяка сила не здатна спинити, як не можна спинити світла «розвидняющогося» дня.

Підзаголовок «De profundis» об'єднує найбільшу частину циклів збірки, щоб показати життя, страждання, сльози, нещастя соціальних низів, скривджених, понівечених, кинутих напризволяще. У перекладі з латинської мови інакомовна фраза означає «з глибин, з низин» [9, с. 43]. Відкриває цю частину збірки цикл «Веснянки», більшість творів якого побудована на паралелізмі, що зіставляє життя людське, сповнене дисгармонії, i життя природи, сповнене гармонії і яскравих барв. Тому так пристрасно ліричне «я» чекає очисної грози в суспільстві, що «людськість, мов красна весна, обновить» [9, с. 47], тому, як казковий лицар, звертається він до землі «всеплодющої» [9, с. 48] матері наповнити його силою, «щяоб в бою сильніше стояти» [9, с. 48], щоб «пута ламати», «в серие кривди влучать» [9, с. 48].

Для громадянської лірики поета властива пристрасність, внутрішня енергія поривання до правди і справедливості, до боротьби зі злом, соціальною неволею. Поет закликає до суспільного оновлення, до пробудження «свіжих надій» [9, с. 50], щоб не наросли «мозолі на руках $i$ душі» [9, с. 50]. Автор персоніфікує природу, образ сонця, що оглядає землю, іiі «велике, непроглядне горе...» [9, с. 52], тому, мов сльози жалю, «на рісницях золотистих дві-три краплиночки зависли» [9, с. 52]. Розквіт і радість у природі дисонує з життям людей, коли вони «з

(ㄱ Л. Б. Стрюк, К. С. Ткачук, 2018. 
роботи перемучені спішать, руки й ноги мов відрубані болять» [9, с. 53]. Природа постає «наче людському нещастю на докір» $[9$, с. 53]. Кожен вірш ніби нанизує біди знедоленого народу, якого переслідують «голод і холод, руїна і страти» [9, с. 53]. Ліричне «я» воліє стати часткою природи, «Щоб не чуть в сериі пекучого болю, Людської муки не бачити скрізь!» [9, с. 54].

Медитаційного характеру набувають рядки, звернені до розуму, щоб той зміг «порвати пута віковії, Що скували думку людську! < ..> Розхитай < ..> ясні думи, Розрости бажання волі <...> Поєднай велику силу <...> Щастя, волі добувати!» [9, с. 55]. Розгорнута метафора сповнена громадянського пафосу, акцентує на необхідності боротьби народу з царством неволі і зла, де «тьма $i$ неволя n'є народну кров» $[9$, с. 56]. Акцентно-виразного значення набувають і епітети «вбогі села», «бідний гине з голоду мужик» $[9$, с. 55], «сумна пісенька» $[9$, с. 56], «понура тюрма» $[9$, с. 56], «скорбне серие моє» $[9$, с. 56], «важка боротьба» $[9$, с. 56] та ін. Поетичні звертання сповнюють громадянську лірику експресією, прагненням передати внутрішній стан ліричного «я», багату гаму його переживань: «Встань, орачу!» [9, с. 47], «Гей брати!» [9, с. 48], «Земле, моя всеплодющая мати» [9, с. 48], «Розвивайся, лозо, борзо, Зелена діброво!» [9, с. 50], «рідне поле» [9, с. 50], «O небо, кришталеве море» [9, с. 52], «Весно, голубко» [9, с. 53], «розуме, бистроуме» [9, с. 55], «Веснянії пісні, Веснянії сни» [9, с. 55], «Ох, живі діброви, Ясний сония світ» [9, с. 55], «Думи, діти мої» [9, с. 56], «Весно, вітре» [9, с. 57], «Люди, люди» $[9$, с. 57] та ін.

Завершує цикл «Веснянки» вірш, що має інакомовну назву «Vivere memento!», у якому відкрито звучить заклик до боротьби, звільнення від «горя домовини» [9, с. 57]. Образ дивного голосу, як голосу духа боротьби і волі, закликає: «Встань, прокинься, пробудись! Vivere memento!». Інакомовна фраза означає: «Пам'ятай, Що живеш!» [9, с. 57]. Цей голос автор називає «крик життя могучий» $[9$, с. 57]. Він висловив своє прагнення боротися 
за щастя людей і «серия свого кров'ю рад горе змити» [9, с. 57]. Метафора-гіпербола передає самовідданість, саможертовність ліричного «я». Вірш завершують рядки афористичного характеру, що виражають авторське кредо: «Лиш боротись значить жить» [9, с. 57]. Ці слова вказують на відкриту громадянську позицію автора служити народу.

У циклі «Осінні думи» образ вітру постає багатогранно. Це і природне явище, i душевний неспокій, i руйнівна сила, i вітер оновлення, змін, і вітер історії, вихор якого може поглинути «слід буття» [9, с. 58] ліричного «я». У вірші «Журавлі» поет подає широку панораму народного зубожіння через художню деталь: «селища бідні», «непошиті хатки», «обдерті і пусті стодоли», «Люд темний, сумовитий, голий» [9, с. 58]. Над усім цим журавлі пролітають «з плачем сумним, мов плач по кращій долі» [9, с. 58]. Автор персоніфікує образ журавлів, передає їх співчуття людській недолі. Ліричне «я» звертається до них 3 проханням взяти його 3 собою, бо він знемагає у країні, що нагадує мглисту і вогку яругу. Суспільні умови підтяли йому крила і він «сохне в тузі» [9, с. 59]. Цей інакомовний образ створює трагіко-драматичну тональність твору, яку підсилює звуконаслідуваний повтор, що нагадує кигикання журавлів «Де ви? Де ви?» [9, с. 59]. Автор прагне розповісти про горе рідного краю усьому світу, зазначивши, що «сірі, безутішні мали < ..> стоять на нашім виднокрузі» [9, с. 59], «про бідність, сльози вічні, про труд безсонний в болю $і$ натузі, про чорний хліб, <..> про спів жалібний» [9, с. 59], «щуоб щзире серие й там ридало» [9, с. 59]. Автор передає власну концепцію дійсності: люди бідні нещасні чи то на «півночі», чи то «в далекім юзі» [9, с. 59]. В одному з творів цього циклу поет подає метафоричний образ заздрості, що «гострі щииці виставляє», якщо «в сериіі людськім зорі золотаві» [9, с. 60]. Цей метафоричний образ малює момент відчуття людського щастя, на яке вже чатують хижі «люті щуки» [9, с. 60]. Прийом інакомовності збагачує художню виразність твору.

(ㄱ Л. Б. Стрюк, К. С. Ткачук, 2018. 
Цикл «Скорбні пісні» починає вірш, у назві якого автор зазначає: «Не винен я тому, щзо сумно співаю» [9, с. 61]. Слова його поезій народжуються «в хвилях недолі, задуми тяжкої», «самі уста їх шепчуть, безсонний робітник заклятий склада їх сум» [9,c. 61]. Матір'ю «скорботних дум» він вважає свою й «народну неволю» [9, с. 61]. Слід зазначити, що автор не дистанціює себе від народу, а вважає невіддільною його складовою, тому горе народне сприймає як власне. Рій «скорбних мислей» [9, с. 61] він порівнює з чорною хмарою, що «небо криє» [9, с. 61]. Ліричне «я» дивиться «поглядом німої злоби <..> на небо й світ живий», сповнений людського горя, в очікуванні, «щзо з земної утроби ось-ось прорвесь огонь страшний І вмить спалить всю землю тую 3 всіма неправдами ї̈» [9, с. 61]. Ці рядки І. Франка нагадують крилаті Шевченкові рядки «сонще зійде $і$ осквернену землю спалить». Як і в Т. Шевченка, у І. Франка відкрито звучить віра в те, що «наче золото в горнилі, Сей світ очиститься зовсім $<\ldots>$ Засяє правда й воля в нім» [9, с. 62]. Він вважає, що його діяльність і творчість сприятимуть споконвічній боротьбі за щасливе майбутнє народу: «До храму людських змагань, пращь $i$ трудів Чень і моя доложиться изеглина» [9, с. 62]. Поет вірить, що «день світла, щастя й волі засвітає» [9, с. 62]. Він висловлює сподівання, що його «хтось добрим словом <...> згадає» [9, с. 62]. Ці рядки перегукуються 3 рядками «Заповіту» Т. Шевченка: «Імене в сім'ї великій, В сім'ї вольній, новій, Не забудьте пом'янути Незлим тихим словом».

Автор потерпає від безсилля змінити антигуманну соціальну систему на досконалу, де панували б воля і правда: «А щзе тяжче гаряче бажати Волі, правди, братньої любови, Шарпатись у путах, гризти крати, А на волю встати не могти» [9, с. 63]. Тяжко переживав I. Франко ув'язнення за революційну діяльність. Його огортав сум, бо «тюремнії стіни» «пожовкли від сліз, Що ними просякли наскрізь» [9, с. 63]. Понуру тюрму він порівнює 3 могилою, тісною і німою $[9$, с. 64]. Низкою риторичних запитань 
поет створює трагіко-драматичну тональність, акцентуючи на гіркому світовідчутті: «За щзо мене тут закували? За щзо мені волю відняли? Кому $і$ чим я завинив? Чи тим, щзо народ свій любив?» [9, с. 64]. Свої погляди на суспільство i свій обов'язок громадянина поет окреслив низкою соціальних орієнтирів, що властиві прогресивній людині: «Бажав я для скованих волі, Бажав для нещасного долі І рівної правди для всіх, - Се весь одинокий мій гріх» [9, с. 64]. Але ці прагнення ліричного «я» стають причиною для його ув'язнення, ізоляції від суспільства, у якому панує жорстокість та антигуманність. Ув'язнення урядом борця за права народу спричинило до того, що від нього «відиуралися люди»: «Сей та той надійде і мине! Тільки боязко скоса зирне» [9, с. 64]. Поет драматизує цю ситуацію, відчуваючи себе затравленим, «мов звір серед гір» [9, с. 64]. Порівняння і метафора «В сериі чую слова, мов докір: «Ти проклятий один серед них!» [9, с. 64] акцентують на відчаї ліричного «я», ладного пожертвувати собою заради щастя людей у країні, щоб не було ні пана, ні рабів [9, с. 65], але це можливе лише в його «снах, у тюрмі» [9, с. 65].

Останню фразу циклу «Скорбні пісні» підхоплюе назва наступного циклу «Нічні думи». Ліричне «я» охоплюють «думки невгамовнії», «невтішні $i$ безконечні» [9, с. 66], а також сум за коханою, з якою його розлучила тюрма. Його він виражає низкою риторичних запитань: «Чи за життя ще я вздрю твоє личенько? Чи аж по смерті на гріб мій, горличенько, Плакать прийдеш?» [9, с. 66]. Автор називає себе «безутішним», а ночі в тюрмі «безкраї», «чорні і сумні» [9, с. 66]. Світовідчуття ліричного «я» передає низка епітетів, що створює ефект драматичного нагнітання. Громадянська лірика поета-борця сповнена розгорнутими метафорами, що акцентують на полум'яних його прагненнях, спрямованих на служіння правді й волі: «Думок сную чорную ткань. I коли ж той жар догорить, Що ятриться у сериі мені? I чи скоро то горе згасить В моїм міску думки огняні? Ox, печуть $і$ бушують вони! Гризе душу й морозить нуда! Кров

С Л. Б. Стрюк, К. С. Ткачук, 2018. 
кипить і нутро все в огни Вколо ж мур і неволя бліда» [9, с. 67]. Ліричне «я» веде внутрішню війну з собою. 3 одного боку він скутий в’язень у «неволі блідій», а з іншого, - його печуть «думки огняні», пов'язані з волею і боротьбою.

У вірші «Не покидай мене, пекучий болю» поет зазначає, що своє призначення бачить у захисті народу, він прагне терзань через людське горе, боїться збайдужіння до лиха людського. Це підкреслюють риторичні конструкції та поетичні звертання: «Не покидай мене, пекучий болю, Не покидай, важкая думо-муко, Над людським горем, людською журбою! <..> Не дай заснуть в постелі безучастя» [9, с. 68]. Поет-борець не хоче думати навіть про «власну радість і про власне щзастя» [9, с. 68], доки круг нього «міліони гинуть» [9, с. 68], «докіль на личях сльози» [9, с. 68], «для прихоті своєї Люд трупом стелють люті тамерлани!» [9, с. 68]. I. Франко звертається, як і Т. Шевченко, до своєї думи, просить днями і ночами закликати його служити людям: «Ти слуга нещасних! Пращюй для них словами і руками Без бажань власних, без вдоволень власних!» [9, с. 69]. Поета обурює засилля в суспільстві «блискучих гнізд розпусти, зіпсуття й обмани», які «світ заражають», спричиняють до того, що «життя тяжким давить валом, На пні ламає силою страшною» [9, с. 68]. Виразні розгорнуті метафори передають у високохудожній формі трагікодраматичне світовідчуття автора.

У вірші «Місяцю, князю!» І. Франко в народнопоетичній манері звертається до небесного світила, що пливе у «воздушному морі», закликаючи «змить з серия горе», знайти цілюще зілля, «щцо лиш иввіте з-за райських меж» [9, с. 69]. Бо навіть місяцю важко дивитись «В людськості бідної Горе безсонне» [9, с. 69], а майбутнє перебуває «в пітьмі» [9, с. 69]. Цю думку автор розгортає d наступному вірші «Пісня геніїв ночі», який завершує цикл. Цей вірш має алегоричний характер. За допомогою лексичної епіфори «Засни», яка посилює алітераційний ряд «з», «с», «ш», «чч» та повторів співзвуч «ст», «сн», «змн», «шч» автор

-211- Л. Б. Стрюк, К. С. Ткачук, 2018. 
передає магічний вплив геніїв ночі. Усі ці засоби створюють приглушеність звучання вірша й уповільнюють емоційний темпоритм. Образ магічної сили геніїв ночі оповитий серпанком таємничості, казковості, екзотичності. Ці алегоричні образи постають втіленням чудодійного навіювання, що спрямоване скувати людей путами забуття, бездіяльності, пасивності у вирішенні власної долі та соціальних проблем, відсторонити від боротьби, стримуючи прагнення до нового, справедливого, щасливого життя. Образ геніїв ночі перегукується 3 образом «Того, що у скелі сидить» 3 драми Лесі Українки «Лісова пісня». Завдання їхнє приспати пристрасті, викликати збайдужіння: «Сюди, вандраче, ти пристань! Засни! Засни! Засни! Що земний илях, щуо земний бій, Ненависть і любов? Тут ніч, тиша і супокій Без снів і без оков. Тут болю, ані втіх нема, Морозу, ні весни, Тут забуття, спокій i тьма - Засни! Засни! Засни!» [9, с. 70]. Триразове епіфоричне повторення в поєднанні з усіма художньообразними та мовностилістичними засобами створює враження навіювання чар геніїв ночі. Це яскравіше виражає ідейно-художнє спрямування вірша створенням звуко-слухового образу, що $\epsilon$ засобом матеріалізації магічних істот. У творі звучить екзистенційний заклик рятуватися від соціальних негараздів та життя, де панує зло, смертю: «Туди верни, відкіль прийшов, Напій безсмертя пий!», «А дух?.. Се огник, нервів рух! Розпадесь мозок, $<\ldots>$ згине дух» [9, с. 70]. Голос геніїв ночі - це голос зневіри в потребі високих поривань до кращого майбуття, це антипод автора, якому той протистоїть своїми справами, своєю творчістю, горінням духу і серця.

У циклі «Думи пролетарія» гнівно звучить голос поетагромадянина, поета-борця, звернений до можновладців: «Судіть мене, судді мої, Без милості фальшивої! Не надійтесь, щуо верну 3 дороги «нечестивої» < ..> Судіть без встиду, таж ви встид На прив'язі тримаєте <..> Та ци ще скажіть, за щуо хотять Перетворити лад ціілий? За те, щзо паном в нім багач, А гнесь

(ㄱ Л. Б. Стрюк, К. С. Ткачук, 2018. 
слугою люд німий < .. > 3 а те, щуо дармоїдство тут 3 робочих рук ссе кров і піт <..> 3 а те, що ллєсь мільйонів кров По прихоті панів, царів; За те, щуо люди людям тут Кати, боги, раби гірш псів $<\ldots>$ А ще скажіть, як сей лад Перевернути хочем ми? <..> Правдою і працею, Й наукою. А як війна Кривава понадобиться Не наша буде в тім вина» [9, с. 71-72]. Це вірш-промова, який автор поставив на захист засуджених за протистояння уряду, що зневажає свій народ та його захисників, борців за звільнення від злотворних соціальних пут.

Вірш I. Франка «Милосердним» звернений до тих, хто дешевими дарами лише погіршує душевний стан пролетаря, принижує його, бо нагадує йому, що він злидар, старець, хоч працює. Автор, щоб виразніше підкреслити соціальну зневагу до трударя, вживає порівняльні звороти, акцентуючи на несправедливості, яка панує в суспільстві: «Нехай $i$ так, щзо, мов черв'як, Затоптаний в багно життя <..> Нехай $i$ так, щуо, в стария мов, Похилий мій, нужденний вид» [9, с. 72]. У вірші подає поет портретну характеристику пролетаря, акцентуючи художньою деталлю на трагіко-драматичному світовідчутті ліричного персонажа: «драний той Блідий, нужденний пролетар $<\ldots>$ лище Не так щасливе, як у вас, <..> уста безкровнії, Погас в очах веселий жар I одіж драна голосно Говорить: «Бач, се пролетар» [9, с. 73]. Низка епітетів («блідий», «нужденний», «раний», «не так щзасливе», «безкровнії» та ін.) вказує на знедоленість та соціальну незахищеність пролетаря, який прагне кращого соціального статусу, «слова прихильного», а не подачок, які зневажають його гідність, що «глибоко грудь ранить» [9, с. 72], «руку наскрізь палив (дар)» [9, с. 73], «вважа Пощочиною всякий дар» $[9$, с. 73]. Як узагальнення звучить твердження автора до милосердних: «А може, дар той, за котрий Вас ваша совість похвалить Його важким зниженням, Мов п'ясть, додолу повалить? Він милість вашу дешеву I руки ваші проклине» $[9$, с. 73$]$. Соціальним докором сильним світу цього поет стає на 
захист найзнедоленіших верств населення, усвідомлюючи, що це його «важкий хрест» [9, с. 73]. Поет усвідомлює свою високу суспільну місію, тому готовий витримати все заради народу: «Проти рожна перти, Проти хвиль плисти, Сміло аж до смерти Хрест важкий нести!» [9, с. 73]. Свою позицію автор окреслює низкою фразеологічних зворотів та піднесеними, сповненими рішучості словами у вірші «Semper idem!» («Завжди те саме»лат.) [9, с. 73]: «Правда проти сили! Боєм проти зла! Між народ похилий Вольності слова!» [9, с. 74]. У вірші звучить впевненість у силу людського духу на шляху до правди, щоб здолати соціальне зло. Афористичного звучання набувають рядки з твору: «Ще те не вродилось Гостреє залізо, Щоб ним правду й волю Самодур зарізав!» [9, с. 74]. Сучасне життя у громадянській ліриці поета найчастіше зіставляється 3 «багном» [9, с. 72], «болотом гнилим» [9, с. 74], але пристосуванці вважали, що «так $\epsilon$ найліпше, як є» [9, с. 74]: «Читали промови, співали поеми Про гарне, щуасливе в болоті життє» [9, с. 74]. Поет прагне відкрити очі громадськості, пристрасно стверджуючи: «Всюди нівечиться правда, Всюди панує брехня» [9, с. 75]. Поет прагне, щоб якнайшвидше зломився «лютий вал лищемірства $і$ зла» [9, с. 75], вірячи, що зрине «з-під зла й пересудів Правда жива на земли!» [9, с. 75]. Це переконання наскрізно проймає громадянську лірику I. Франка.

Глибоким філософським змістом сповнений вірш «Супокій», у якому автор подає різні суспільні ситуації, у яких немає місця супокою, бо «супокій - святеє діло В супокійнії часи» [9, с. 75]. Немає місця супокою, на думку поета, «в час війни та бою» [9, с. 76], коли «в нашу хату $і$ комору Закрадаєсь лиходій, Щоб здобуток наш розкрасти, Ще й на нас кайдани вкласти» [9, с. 76], коли цей лиходій «мисль нашу, мову, совість, мов будяччя, тне $з$ плеча» [9, с. 76]. Саме в ці важкі хвилини для країни і народу не місце супокою. Він полум'яно застерігає: «Горе, хто тоді нас мирить, Хто не рветься до сокири, До коси та до меча» [9, с. 76]. Горе також і тому, вважає поет, «хто підносить самовільную

(ㄱ Л. Б. Стрюк, К. С. Ткачук, 2018. 
війну» [9, с. 76] у часи процвітання країни: «...коли народи в згодi Враз працюють, щзоб природі Вирвать тайну не одну» [9, с. 76]. Про такі часи поету залишалося лише мріяти і своїм словом, i ділами наближати їх. Він прагне, щоб рівняли «по всій земли стежку правдi» [9, с. 77]. На його думку, лише служіння правді об'єднує всіх борців, він виступає проти ідейних чвар, застерігає своїх товаришів по боротьбі, що в пізніші часи «ім'я $i$ діла вамі прокленуть <..> I вашу добру славу оплюють Брехнею, й вас полічать між злодіі, Отрутою замучених напоять Надії ясні жовчю затроять. На суд потягнуть вас, начинять вами Всі тюрми, все покличуть проти вас - Людей $i$ бога» [9, с. 76]. I. Франко риторичним запитанням спонукає зупинитися у ворожнечі між «старими» $\mathrm{i}$ «новими» «гордими лицарями» боротьби: «Чи ж так живуть з людьми-братами люди?» [9, с. 76].

Наступний вірш у квінтесентній формі вже своєю назвою констатує мудрість, до якої прийшов сам поет у процесі боротьби: «Не люди наші вороги» [9, с. 77]. Він впевнено заявляє: «Не люди намі вороги, Хоч люди гонять нас $і$ судять, I запирають до тюрми, I висмівають нас, і гудять» [9, с. 77]. Поет переконаний, що причиною зла є соціальна система, яка в'яже своїми законами на підтримку сильних світу цього все суспільство. Він стверджує цю думку поетичними рядками: «Не в людях зло, а в путах тих, Котрі незримими вузлами Скрутили сильних і слабих 3 їх мукою $i$ ïх ділами» [9, с. 77]. Поет використовує образ-естафету, узятий із античності, увівши цей образ у порівняльну конструкцію, щоб зриміше передати потугу в соціальній боротьбі: «Мов Лаокоон серед змій, Так люд увесь в тих путах в'ється <...> Ох, іколи ж той скрут страшний На тілі велетня порветься?» [9, с. 77]. Риторична конструкція посилює драматизм звучання твору, акцентує на його ідейно-художньому спрямуванні, зримості образу народу, скутого соціальними путами, i бажанні їх розірвати. Удаючись до інакомовної форми, поет прагне звільнити народ шляхом знищення соціальної системи пригнічення.

-215- Л. Б. Стрюк, К. С. Ткачук, 2018. 
Цикл «Excelsior!» (3 вершин - лат.) [9, с. 79] відкриває вірш «Наймит», що складається з трьох частин. У першій частині постає образ знедоленого, зневаженого наймита, у якого «нестаток $i$ тяжка робота, і натуга Зорали зморшками чоло, Немов дідусь слабий <..> Сіряк, чуга На нім, мов на стариеві, з пошарпаної свити <..> Сам хилиться в ярмо. Щоб жити, він життя, $і$ волю власну, й силу За хліба кусник продає <..> Сумує німо він, з тужливим співом оре... Потом труду свого Панам панування дає» [9, с. 79-80]. Автор виражально-зображальними епітетами акцентує на трагіко-драматичному світовідчутті ліричного персонажа: «мужлливий спів», «тяжкка робота», «нужда безвихідна», «піт кривавий». У другій - цей образ набуває переосмислення. 3 образом упослідженого наймита зіставляється український народ: «Той наймит - наш народ, щэо поту лле потоки Над нивою чужою Все серием молодий, думками все високий, Хоч топтаний судьбою <...> Руйни перебув, татарські лихоліття I панщини ярмо тверде $<\ldots>$ В століттях нагніту його лиш рятувала Любов до рідних нив <...> 3 любов'ю тою він - мов велетень той давній, Непоборимий син землі, Що, хоч повалений, оп'ять міџний $і$ славний, Вставав у боротьбi» [9, с. 80]. Поет возвеличує образ народу з його тяжким історичним минулим i 3 палкою любов'ю до рідної землі, який готовий піднятись на боротьбу за краще майбутнє, бо він «непоборимий син землі» $[9$, c. 80]. У третій частині твору автор називає народ «велетнем закутим» $[9$, с. 81], він вірить, що 3 нього «обпадуть пута» [9, с. 81]. Поет висловлюе надію, що «ярма всі ми порвемо» [9, с. 81], і віру, що «він побідить» [9, с. 81]. Заклично і впевнено звучать рядки, звернені до народу, які перегукуються 3 «Заповітом» Т. Шевченка: «I вольний власний лан Tи знов оратимеш - властивець свого труду I в власнім краю сам свій $n a н \gg[9$, c. 81]. Мотив вільного життя для народу є наскрізним для громадянської лірики І. Франка. Поет прагне бачити народ господарем своє долі, своєї праці, свого краю.

( Л. Б. Стрюк, К. С. Ткачук, 2018. 
Наступний вірш «Беркут» складається 3 чотирьох частин. У першій частині образ беркута постає як образ високогірного птаха, що сягає «nid хмари сині» [9, с. 81]. Авторові здається, що цей могутній птах може «облетіти світ, $i$ аж о неба звід опреться» [9, с. 81]. 3 цим образом зіставляється «гнівлива думка», яка, облетівши світ, зве: «Де правда та? Де ти, великий боже?» [9, с. 81]. Риторичні запитання посилюють соціальне звучання твору. У другій - образ беркута постає як образ хижого птаха: «В блакиті він завис недвижний, розпростертий, Мов над життям грізний, невпинний образ смерти» [9, с. 81]. Він завжди прагне «кров пролити» [9, с. 81], він навіває жах. У першій і другій частині твору образ орла постає як народнопісенний символ вольності i міфологічний посланець потойбічного царства. Звертаючись до уявного читача, поет застерігає, надаючи цьому образу певної інакомовності: «Таж над тобою тож завис беркут нестримний! Він не хибне тебе, хоч як високо висить! Чи много то ще хвиль тобі гуляти лишить?..» [9, с. 81]. Поет натякає, що в суспільних верхах $є$ людолови, які чатують на кожного. Це одночасно перегукується 3 образом дамоклового меча чи лихої долі, рока.

Інакомовність образу беркута закріплюється у третій частині твору. Поет зіставляє беркута 3 човником Долі, що «тче днів наших пасма скриті» [9, с. 82]. Почувши його хижий крик, «в час тиші не раз прорветься плач народний» [9, с. 83]. У трактовці образу автор рухається від окремого до загального, від окремої особистості до узагальненого образу народу. Інакомовність образу розкривається в четвертій частині твору, набуваючи певної алегоричності. Автор гнівно звертається до беркута: «Я не люблю тебе, ненавиджу, беркуте! За те, щзо в груді ти ховаєи серцуе люте, За те, щуо кров ти п'єщ, на низьких і слабих 3 погордою глядиш, хоч сам живеш із них, За те, щзо так тебе боїться слабша твар, Ненавиджу тебе за теє, щзо ти цүар!» [9, с. 82]. Загрозливо у творі звучать слова автора про те, що він готовий знищити

-217- Л. Б. Стрюк, К. С. Ткачук, 2018. 
беркута, і той сам «спіткає смерть під хмарами» [9, с. 82]. Поет попереджає, що на таких же, як він, «є стрільиів стосот» [9, с. 82]. Образ беркута у творі виростає до образа-символа хижої, необмеженої влади, що натякає на самодержавний герб. Автор надає образу узагальнення: «I все, щзо звесь беркут, полоще кров’ю рот, Вивищуєсь над мир, тривогу й пострах сіє» [9, с. 82]. У той же час поет пророкує безжальне знищення можновладців, що провадять антинародну політику в суспільному житті.

Алегоричний характер має і вірш «Каменярі» I. Франка, що завершує збірку «3 вершин i низин». У ньому набуває переосмислення образ каменярів, що виростає з образу звичайних будівників доріг до образу борців, що прокладають народу шлях у щасливе майбутнє. Завдяки цьому віршу образ самого I. Франка співвідноситься з образом невтомного каменяра, що рушить скелю деспотизму, соціальної несправедливості. Велику художню роль у творі відіграє синонімічний повтор до слова «дорога»: «Що аж тоді підуть по тій дорозі люди, Як ми проб'єм ї̈ $і$ вирівнясм всюди, Як наші кості тут під нею зогніють» [9, с. 86], «На шляху поступу ми лиш каменярі» [9, с. 86], «Що кров'ю власною $i$ власними кістками Твердий змуруємо гостинець $і$ за нами Прийде нове життя, добро нове у світ» [9, с. 86], «Ми ломимо скалу, рівнясм правді путі. І щзастя всіх прийде по наших аж кістках» $[9$, c. 86].

У цьому вірші за допомогою синонімічного ряду: «дорога», «шлях», «гостинецьь», «путі», вибудувано асоціативні поля, що помітно збагачують образ дороги, надають йому нового наповнення завдяки контексту. У семантиці цих слів відчутна певна градація: у нашій уяві виникає спочатку «дорога», обмежена просторово, потім цей образ дещо розширюється і це вже «шлях», що губиться в безмежному просторі, а потім «гостинець», який ніби розгалужується на безліч «путів». Виходячи 3 контексту, можемо помітити, що смислове значення слів змінюється. Вони вжиті у вірші не лише у своєму прямому значенні, але й

(С Л. Б. Стрюк, К. С. Ткачук, 2018. 
у переносному. Зокрема, словосполучення «шлях поступу» сприймається у значенні «шлях боротьби». Саме це сприяє переосмисленню алегоричного образа каменярів. I в уяві постають уже не звичайні будівники доріг, що розбивають камінні брили, а борці, які прокладають шлях до нового щасливого майбуття, руйнуючи скелю деспотизму. Словосполучення «рівняєм правд nymi» в художньому контексті сприймається у значенні боротьби за правду, щастя, нове життя, до якого прагнуть прокласти шлях каменярі, хай навіть ціною свого життя. Автор вводить у твір словосполучення, що синонімічні слову «смерть»: «намі кості тут під нею зогніють», «кров'ю власною $і$ власними кістками твердий змуруємо гостинещь», «Щастя всіх прийде по наших аж кістках». Цей синонімічний повтор створює певне драматичне нагнітання, посилює емоційно-смислове наповнення твору.

Отже, дослідивши громадянську лірику I. Франка зі збірки «3 вершин i низин», нам вдалося простежити характер співвідношень: людина i суспільство, людина i природа, що найповніше виражають динамічне співвідношення ідеалу й дійсності. Так, у поезіях збірки автор, за його визнанням, хотів показати першу спробу реальної, «на живих фактах обпертої і за реальним способом обробленої поезії». Аналізуючи твори, ми побачили, що поет акцентував на тому, що не в людях зло, а в тих суспільних обставинах, які спонукають їх до тієї чи тієї дії, у соціальних путах системи, що сковують всіх. Автор відкрито заявляє: «Всюди нівечиться правда, Всюди панує брехня». Він прагне, щоб зломився «лютий вал лицемірства $i$ зла».

У творах відображено віру I. Франка в людину, у можливість пробудження в ній за сприятливих умов кращих рис. Він вірить у торжество правди на землі. Носієм позитивного постає в його творах селянська родина на тлі щедрої природи. Поет намагається проникнути в психологію трудящої людини, іiі світовідчуття. У збірці поет зображує потворні явища дійсності: неволю, гніт, підлість, злість, зневагу, бідність, приреченість, голод та ін. 
Чимала частина творів має трагіко-драматичну тональність, що зумовлена безпосередньою участю ліричного «я» в непримиренному конфлікті 3 антигуманною дійсністю, усвідомленням неможливості здійснення високого ідеалу в сучасних умовах. У збірці контрасти соціального життя «низин», картини приниження людини ідуть поруч із мотивами їх величі та духовної сили. У поетичному розкритті багатогранних сторін i виявів життя I. Франко вдається до улюбленого ним ряду образів (вогню, хмар, грому, зливи, вітру, сонця, зірок). Одне 3 принципових світоглядних переконань поета - його розуміння великої суспільно-впливової сили слова. Як показало дослідження, громадянська лірика I. Франка відзначається помітним ідеологічним підтекстом, лейтмотивом боротьби 3 соціальним злом, публіцистично-романтичною риторикою, уславленням вольового ствердження особистості людини-борця за прогресивні загальнолюдські та загальнонародні ідеали. Громадянська лірика поета інтелектуальна за змістом і драматична за пафосом. Вона відзначалася соціальним оптимізмом, вірою в неминучість перемоги добра над злом, світла над темрявою.

Мова творів I. Франка афористична («Горе тому, хто підносить Самовільную війну», «не в людях зло, а в путах тих, Котрі незримими вузлами Скрутили сильних і слабих з йх мукою $і$ їх ділами», «Сій, хоч не твойов Руков пожате буде жниво!», «В власнім краю сам свій пан», «Ніде той не дійде, Хто не має изілі», «Пісня $і$ праця - великі дві сили! Їм я до скону бажаю служить», «В пісні те лии живе, щь життя дало», «Ні, хто не любить всіх братів, Як сонце боже, всіх зарівно, Той щчиро полюбить не вмів Тебе, коханая Вкраӥно!», «В наших сериях сила, Котрої ржа спідлення не з їсть», «Не знає стін, перегород любов», «Де поставить кого доля, Там і стій!», «Судіть мене, та вас осудить час!», «Любов людей, мов хліб той до засіка, Громадь $i$ степенуй в любов до чоловіка!», «Хто з злом не боресь, той людей не любить» та ін.). Його лірика багата на художні засоби.

(ㄱ Л. Б. Стрюк, К. С. Ткачук, 2018. 
Найбільш активно поет використовує епітети як виражальні, так і зображальні, порівняння, розгорнуті і нерозгорнуті, різнопланові зіставлення, метафори, антитези, паралелізми, стилістичні фігури та інше задля того, аби розставити смислові акценти, увиразнити ідейно-художнє спрямування твору, передати особливості світовідчуття автора, ліричного героя чи ліричного «я».

\section{Література}

1. Білецький О. I. Поезія Івана Франка / О. І. Білецький // Українські дожовтневі письменники: зб. літературно-критичних матеріалів / упоряд. : В. Ф. Шевченко. - К. : Рад. школа, 1985. - С. 192-197.

2. Гундорова Т. І. Іван Франко / Т. І. Гундорова // Історія української літератури XIX століття : у 2-х кн. - Кн. 2 : підручник / за ред. акад. М. Г. Жулинського. - К. : Либідь, 2006. - С. 268-349.

3. Дубина М. Іван Франко / М. Дубина // Українська література. - К., 1996. $256 \mathrm{c}$.

4. Єфремов С. Іван Франко : Критично-біографічний нарис / С. Єфремов. - К., 1926. - C. 170.

5. Клочек Г. Літературна освіта в новій українській школі: стратегія і тактика реформування / Г. Клочек // Дивослово. - 2017. - № 2. - С. 2-11.

6. Романенко О. Екзистенційна апологія боротьби (до проблеми ліричного героя Івана Франка) / О. Романенко // Літературознавчі студії. - Вип. 18. - К. : ВПЦ «Київський університет», 2006. - С. 100-104.

7. Ткачук М. Духовні шукання героя-екзистенціала у збірці «Із днів журби» Івана Франка / М. Ткачук // Література. Фольклор. Проблеми поетики : зб. наук. праць. - Вип. 24. - Ч. 1. - К. : Акцент, 2006. - С. 35-58.

8. Токмань Г. Українська літературна освіта: з погляду вічності й у контексті сьогодення / Г. Токмань // Дивослово. - 2017. - № 3. - С. 2-6.

9. Франко І. Я. Вибрані твори : у 3-х т. / Іван Франко. - Т. 1. - К. : Дніпро, 1973. $-759 \mathrm{c}$.

Стаття надійшла до редакиії 28.02.2018 p.

-221- Л. Б. Стрюк, К. С. Ткачук, 2018. 